\title{
Dosimetric Advantages of Active Tracking and Dynamic Dose Delivery
}

\author{
I. Buzurovic \\ Thomas Jefferson University and Hospitals \\ K. Huang \\ Thomas Jefferson University and Hospitals \\ M. Werner-Wasik \\ Thomas Jefferson University and Hospitals \\ T. Biswas \\ Thomas Jefferson University and Hospitals \\ J. M. Galvin \\ Thomas Jefferson University and Hospitals. \\ Follow this and additional works at: hittps://jdc.jefferson.edu/bodinejournal \\ Part of the Oncology Commons

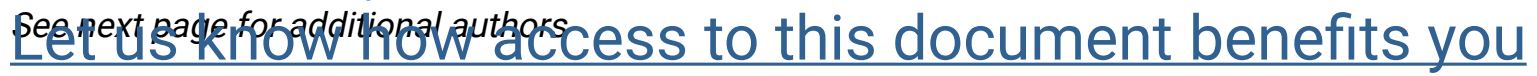

\section{Recommended Citation}

Buzurovic, I.; Huang, K.; Werner-Wasik, M.; Biswas, T.; Galvin, J. M.; Dicker, A.; Yu, Y.; and Podder, T. (2010) "Dosimetric Advantages of Active Tracking and Dynamic Dose Delivery," Bodine Journal: Vol. 3 : Iss. 1 , Article 9.

DOI: https://doi.org/10.29046/TBJ.003.1.008

Available at: https://jdc.jefferson.edu/bodinejournal/vol3/iss1/9

This Article is brought to you for free and open access by the Jefferson Digital Commons. The Jefferson Digital Commons is a service of Thomas Jefferson University's Center for Teaching and Learning (CTL). The Commons is a showcase for Jefferson books and journals, peer-reviewed scholarly publications, unique historical collections from the University archives, and teaching tools. The Jefferson Digital Commons allows researchers and interested readers anywhere in the world to learn about and keep up to date with Jefferson scholarship. This article has been accepted for inclusion in Bodine Journal by an authorized administrator of the Jefferson Digital Commons. For more information, please contact: JeffersonDigitalCommons@jefferson.edu. 
Dosimetric Advantages of Active Tracking and Dynamic Dose Delivery

Authors

I. Buzurovic, K. Huang, M. Werner-Wasik, T. Biswas, J. M. Galvin, A. Dicker, Y. Yu, and T. Podder 


\title{
Dosimetric Advantages of Active Tracking and Dynamic Dose Delivery
}

\author{
Buzurovic, I., Huang, K., Werner-Wasik, M., Biswas, T., Galvin, J.M., Dicker, A., Yu, Y., Podder, T. \\ Department of Radiation Oncology, Thomas Jefferson University and Hospitals, Philadelphia, PA
}

\section{Purpose}

To investigate dosimetric effect of tumor tracking. To evaluate changes of treatment volumes when tracking is applied.

\section{Method and Materials}

Tumors in thorax region incur significant amount of motion and deformation due to respiratory and cardiac cycles. In this study, volumetric and dosimetric effect of tumor motion tracking have been investigated. We have analyzed data for ten patients who were diagnosed with lung cancer. In order to make dosimetry comparison, the treatment plan was made for each of ten phases of tumor motion. The dosimetric and volumetric effects were analyzed for two groups of tumor motion. In the first group tumor motion was up to $1.5 \mathrm{~cm}$, whereas for the second the motion was up to $2.5 \mathrm{~cm}$.

\section{Results}

It was observed that during respiratory cycle GTV was changed from $1-3 \mathrm{~cm}^{3}$ for GTVs around $20 \mathrm{~cm}^{3}, 5 \mathrm{~cm}^{3}$ for GTVs around $50 \mathrm{~cm}^{3}$, and $20 \mathrm{~cm}^{3}$ for GTVs of $100 \mathrm{~cm}^{3}$ and above, depending on tumor position and respiratory cycle itself. When active tracking was applied and tumor motion was up to $1.5 \mathrm{~cm}$, irradiated PTV was from $20-30 \%$ less for medium size tumors and more than $50 \%$ for small size tumors. For tumor motion range up to $2.5 \mathrm{~cm}$, irradiated PTV was two times smaller when tracking is applied. It was noticed that V20 with tracking was from 2-15\% less of V20 without tracking, for tumor motion up to $1.5 \mathrm{~cm}$. For tumors within motion range from $2.2 \mathrm{~cm}$ to $2.5 \mathrm{~cm}$, V20 with tracking was from $11-30 \%$ less comparing to one without tracking. Calculating dose it was concluded that $20 \%$ of healthy lung approximately receives from $2 \mathrm{~Gy}$ to $6 \mathrm{~Gy}$ less when tumor tracking technique was used.

\section{Conclusion}

Implementation of real-time tracking techniques can minimize irradiation to healthy tissues and improve sparing of critical organs. Consequently, quality of patient treatment potentially can be improved.

Acknowledgement: Study supported by Elekta, Ltd. 